\title{
Improving the Performance of Shell-and-Tube Heat Exchangers by the Addition of Swirl
}

DOI:

10.1504/IJPSE.2014.066691

\section{Document Version}

Accepted author manuscript

Link to publication record in Manchester Research Explorer

\section{Citation for published version (APA):}

Abeykoon, C. (2014). Improving the Performance of Shell-and-Tube Heat Exchangers by the Addition of Swirl. International Journal of Process Systems Engineering, 2(3), 221-245. https://doi.org/10.1504/IJPSE.2014.066691

\section{Published in:}

International Journal of Process Systems Engineering

\section{Citing this paper}

Please note that where the full-text provided on Manchester Research Explorer is the Author Accepted Manuscript or Proof version this may differ from the final Published version. If citing, it is advised that you check and use the publisher's definitive version.

\section{General rights}

Copyright and moral rights for the publications made accessible in the Research Explorer are retained by the authors and/or other copyright owners and it is a condition of accessing publications that users recognise and abide by the legal requirements associated with these rights.

\section{Takedown policy}

If you believe that this document breaches copyright please refer to the University of Manchester's Takedown Procedures [http://man.ac.uk/04Y6Bo] or contact uml.scholarlycommunications@manchester.ac.uk providing relevant details, so we can investigate your claim.

\section{OPEN ACCESS}




\title{
Improving the performance of shell-and-tube heat exchangers by the addition of swirl
}

\author{
Chamil Abeykoon \\ School of Engineering and Applied Physics, \\ Glyndwr University, \\ Wrexham, LL11 2AW, UK \\ E-mail: c.abeykoon@glyndwr.ac.uk \\ E-mail: yabeykoon01@qub.ac.uk
}

\begin{abstract}
Heat exchanger is a component which is used to transfer the heat from one medium to another efficiently. Generally, they occupy a large space compared to other components and such bulky designs are not attractive in the modern industrial applications due to several constraints. Therefore, it is invaluable to develop compact heat exchangers but with the improved performance. In this work, an investigation was made on the possibility of reducing the size of a shell-and-tube heat exchanger by addition of swirl. Swirl was generated by using a twisted-tape which inserted inside tube and the effects of these tapes on the heat transfer rate and pressure drop were theoretically studied. The results showed that a half-length regular spaced twisted-tape insert gave the lowest Nusselt number while a full-length twisted-tape insert gave the maximum Nusselt number and hence the highest rate of heat transfer. The length of the heat exchanger could be reduced by $13.3 \%$ with a full-length twisted tape and this would be result in $6.8 \%$ of reduction of the fabrication cost. Therefore, addition of swirl into the fluid flow should help to design compact and low cost heat exchanges with improved performance but the pressure drop increased leading to an increase of the required pumping power. A prototype shell-and-tube heat exchanger was designed and fabricated based on the theoretical results. Studies are underway to experimentally investigate the overall effectiveness of the use of twisted-tape inserts for enhancing the heat transfer rate by considering all the related benefits and drawbacks.
\end{abstract}

Keywords: heat exchanger; heat transfer coefficient; non-dimensional numbers; swirl flow; twisted-tape; compactness; pressure drop; cost analysis.

Reference to this paper should be made as follows: Abeykoon, C. (2014) 'Improving the performance of shell-and-tube heat exchangers by the addition of swirl', Int. J. Process Systems Engineering, Vol. 2, No. 3, pp.221-245.

Biographical notes: Chamil Abeykoon received his BSc in Mechanical Engineering from the University of Peradeniya, Sri Lanka, with the award of the best performance in mechanical engineering in 2007. He received his $\mathrm{PhD}$ in Mechanical Engineering from the Queens University Belfast, UK, in 2011 with 18 research publications, a patent application and a young author best paper award from the IEEE. After his $\mathrm{PhD}$, he briefly worked as a Lecturer in Mechanical Engineering at the University of Peradeniya, Sri Lanka, and as a Research Fellow in Engineering at the University of Bradford, UK. Currently, he is a Lecturer in Engineering at the Glyndwr University, UK. So far, he has produced 15 journal papers and 15 conference papers. Moreover, he is the author of the book Polymer Extrusion: A Study on Thermal Monitoring Techniques and Melting Issues. His current research interests include process 
monitoring, modelling and control; soft sensors and soft sensing; process instrumentation; energy efficiency; and heat transfer. $\mathrm{He}$ is an associate member of the IESL, IMechE, and ICPM.

\section{Introduction}

Heat transfer can occur in several ways such as conduction, convection, radiation, etc. Usually, the heat is naturally released to the surroundings from systems/machines by means of one or many of these ways. However, the forced cooling is a requirement of removing the additional heat generated in some applications to ensure the effective/efficient operation. In such applications, heat exchanges are commonly used for removing the additional or unnecessary heat. Usually, heat exchangers remove the heat of a particular medium by allowing it to absorb into another heat transfer medium such as water, oil, air, etc. Currently, numerous heat exchanging techniques are available and are widely used in the applications such as refrigeration, air conditioning, automobiles, process industry, solar water heater systems, thermal power plants, and so forth. In some particular applications, heat exchangers which are bulky in size have to be used based on the amount of the heat required to be removed from the system for a given time to maintain the desirable temperature limits. However, the size of the components/machines has become a major consideration in the modern industrial world due to the constraints such as space limitations, maintenance requirements, portability, manufacturing cost, appearance, etc. Therefore, the size of the heat exchanger has also become a critical factor which would decide the size of some particular machines/plants. Under these circumstances, extensive researches have been carried out during the last few decades to reduce the size and the fabrication cost of the heat exchangers.

\subsection{Heat exchanger}

Basically, the heat exchange can occur via both convection and conduction within a heat exchanger. Moreover, the radiation heat transfer between the exchanger and the environment can usually be neglected if the exchanger has been insulated or its external surfaces are not very hot. Heat exchangers are usually divided into three categories based on their flow arrangement as discussed below (Incropera and Dewitt, 2002):

\subsubsection{Parallel-flow}

It is known as the parallel flow arrangement when the two fluids flow in the same direction and the each of the fluids enters the heat exchanger at the same end as shown by solid arrows in Figure 1.

\subsubsection{Counter-flow}

When fluids are entering to the heat exchanger at the opposite ends and also they are flowing in the opposite directions to each other as shown by dashed arrows in Figure 1, this is known as the counter flow arrangement. Of these three types, counter flow heat exchangers are the most efficient (Incropera and Dewitt, 2002; Wang et al., 2009). In 
contrast with the parallel flow heat exchangers, the counter flow heat exchangers can have a higher temperature of the exit cold fluid than the outlet temperature of the hot fluid.

Figure 1 A schematic of a heat exchanger (see online version for colours)

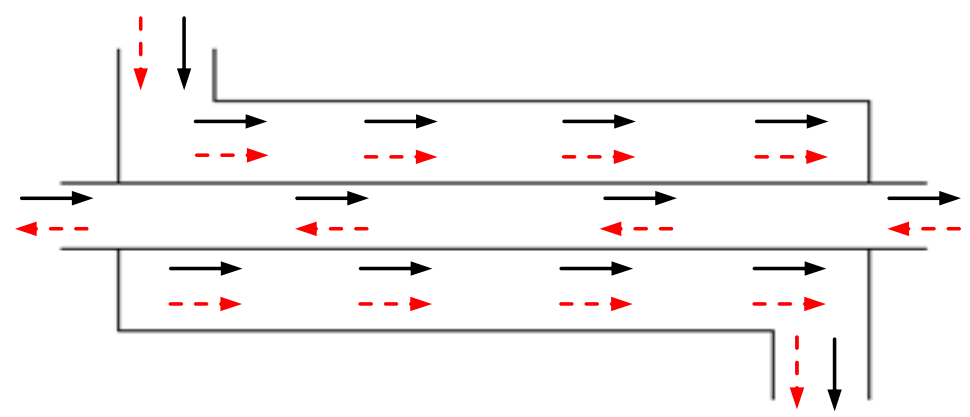

Notes: Solid arrows - the parallel flow arrangement

Dashed arrows - the counter flow arrangement

\subsubsection{Cross-flow}

Cross-flow heat exchangers are commonly used in the air or gas heating/cooling applications. In the cross-flow arrangement, a fluid may be forced across a tube bundle while another fluid is used inside the tubes for heating or cooling process as shown in Figures 2(a) and 2(b).

Figure 2 (a) A two-pass cross flow (b) Typical tubular morphology of a cross-flow heat exchanger (see online version for colours)

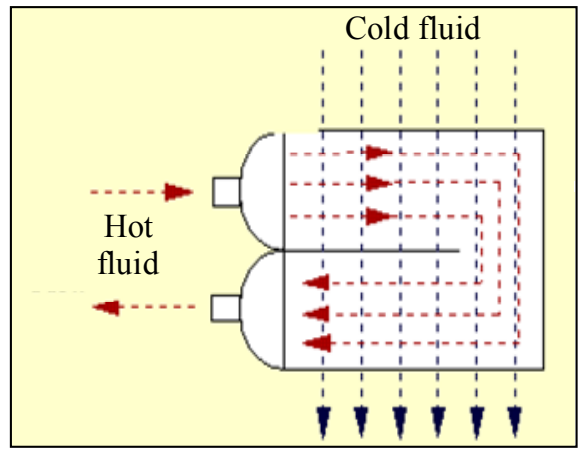

(a)

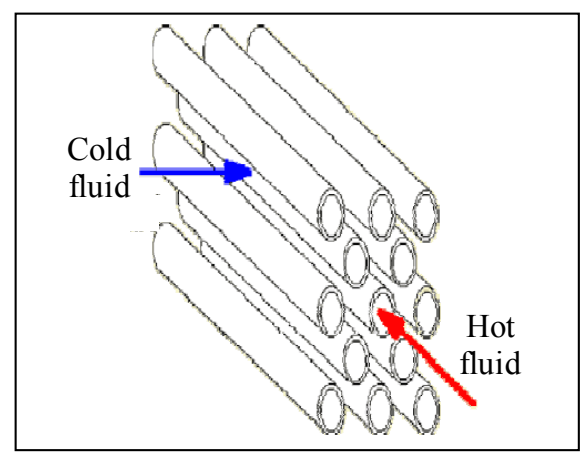

(b)

Here, the fluid flowing across the tubes is known as the mixed stream while the fluid in the tubes is called as the unmixed stream. The fluid flowing across the tubes can mix because it can move around freely inside the exchanger as it exchanges the heat. The other fluid is confined into separate tubular channels and hence it cannot mix with itself during the heat transfer process. 


\subsection{Shell-and-tube heat exchanger}

Shell-and-tube heat exchangers are widely popular in petrochemical and energy industries due to their simplicity in design/manufacture and also the capability of adapting to different operating conditions (Wang et al., 2009). A typical arrangement of a shell-and-tube heat exchanger is shown in Figure 3.

Figure 3 A shell-and-tube heat exchanger with one shell pass and one tube pass (cross and counter flow operation) (see online version for colours)

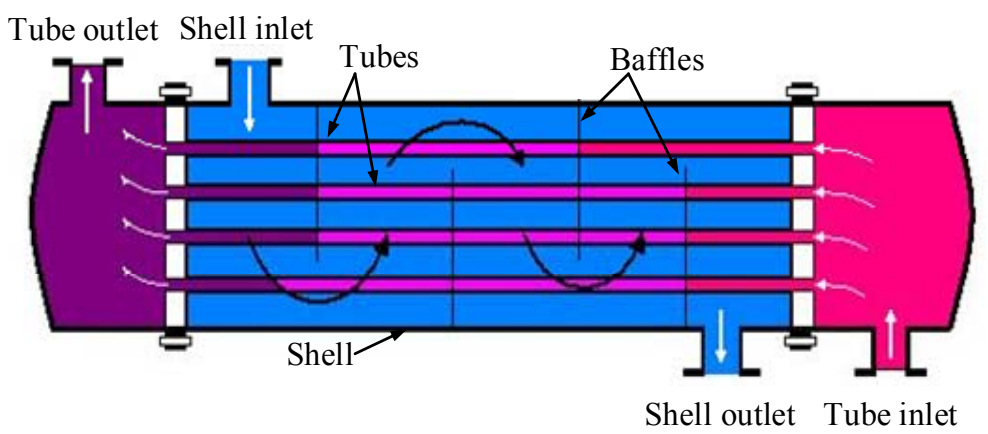

As shown in Figure 3, one of the fluids flows inside the tubes while other fluid is forced through the shell and over the outside surfaces of the tubes. Baffles are placed inside the shell to ensure a good circulation of the fluid within the shell across the tubes and hence they help to induce a high rate of heat transfer (Eryener, 2006). Moreover, the baffles with various shapes/arrangements/spacing are used in the practical applications. One or more tube passes may be utilised depending on the head arrangement at the ends of the exchanger. Furthermore, the heat transfer performance of the heat exchangers may reduce as they become older particularly due to fouling and scaling. More details on the design and operation of heat exchangers can found in the literature (Incropera and Dewitt, 2002; James et al., 2001).

In this work, an investigation was made to improve the performance of a shell-and-tube heat exchanger by addition of swirl. The study was performed under three major aims:

- $\quad$ select an efficient method for introducing swirl to the fluid flow/flows inside a shell-and-tube heat exchanger

- compare the performance (e.g., heat transfer rate, pressure drop, fabrication cost) of a shell-and-tube heat exchanger with and without swirl

- design and fabrication of a prototype heat exchanger to use in the experimental evaluations. 


\section{Addition of swirl to the shell-and-tube heat exchangers}

In general, heat transfer enhancement techniques can be classified into three major categories (Kumar and Murugesan, 2012; Kumbhar and Sane, 2010):

- Active methods: These involve in improving the heat transfer rate via techniques that require extra external power sources, for example, mechanical aids, injection and suction of the fluid, surface-fluid vibration, jet impingement, use of electrostatic fields, etc. However, these methods may have limitations in practical applications due to their requirement of external power sources.

- Passive methods: These perform the work passively (i.e., without any involvement of external power sources) by improving the heat exchanger with various possible techniques such as addition of a surface coating, roughing of surfaces, extended surfaces, placing of swirl flow generators across the flow, addition of swirl to the flow channel, use of additives with liquids/gases, etc. These methods seem to be attractive in practical applications particularly due to their simplicity and low cost.

- Compound methods: If a system uses any two or more active or passive techniques to improve the rate of heat transfer, it is known as a compound method.

In fact, the performance of heat exchangers can be improved passively by addition of swirl (Eiamsa-ard and Promvonge, 2005). Placing of a twisted-tape is a good way of adding swirl to the fluid flow and two types of swirl flow devices are widely popular in the industry: the continuous swirl flow and the decaying swirl flow devices. In a continuous swirl flow, the swirling motion exists over the whole length of the tube (e.g., twisted-tape inserts and wire coil inserts) while heat transfer coefficient and pressure drop keep constant with the axial distance (Manglik and Bergles, 1993a, 1993b; Hong and Bergles, 1976; Eiamsa-ard et al., 2004a). In a decaying swirl flow, the swirl motion is generated at the entrance of the tube and decays along the flow path (e.g., the radial guide vane swirl generator, snail swirl generator and the tangential flow injection device) while heat transfer coefficient and pressure drop decrease with the axial distance (Chang and Dhir, 1995; Yildiz et al., 1996). To improve the rate of heat transfer, it is required to increase the convective heat transfer coefficient which comes under the forced convection. This can be achieved by increasing the convection coefficient or/and by increasing the convection surface area, and schematic diagrams showing some of the possible methods of improving the rate of heat transfer are presented in Figures 4-9.

Figure 4 A schematic showing a twisted-tape placed inside the tube

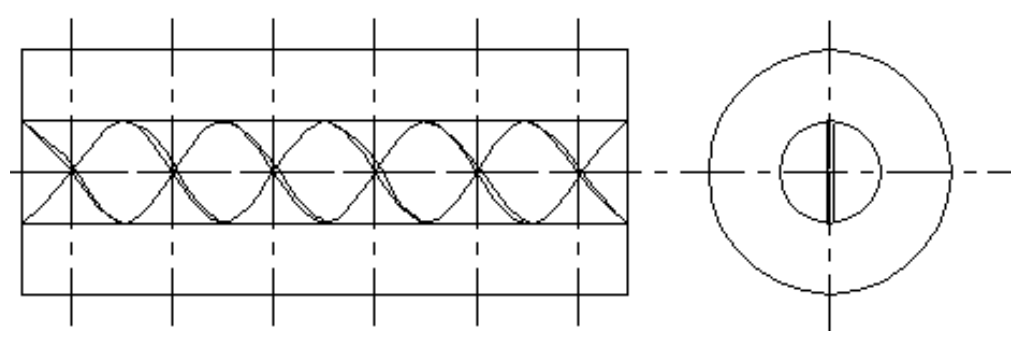


Figure 5 A schematic showing a propeller placed inside the tube

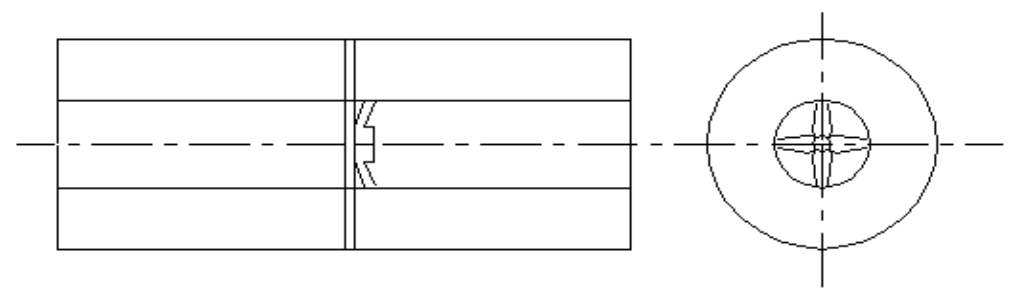

Figure 6 A schematic showing a shell and a tube with wavy surfaces

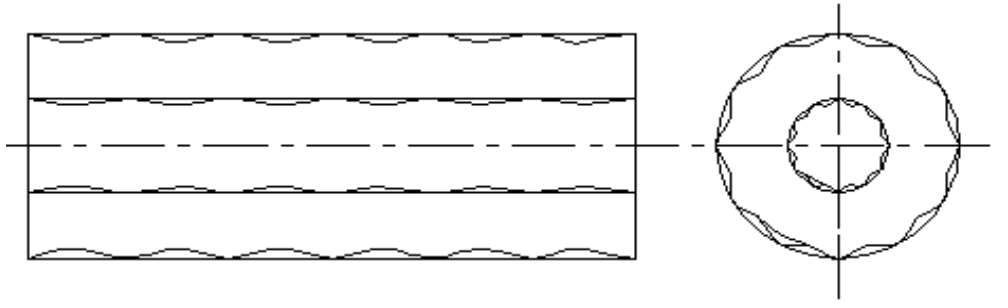

Figure 7 A schematic showing a few spiral windings placed inside the tube

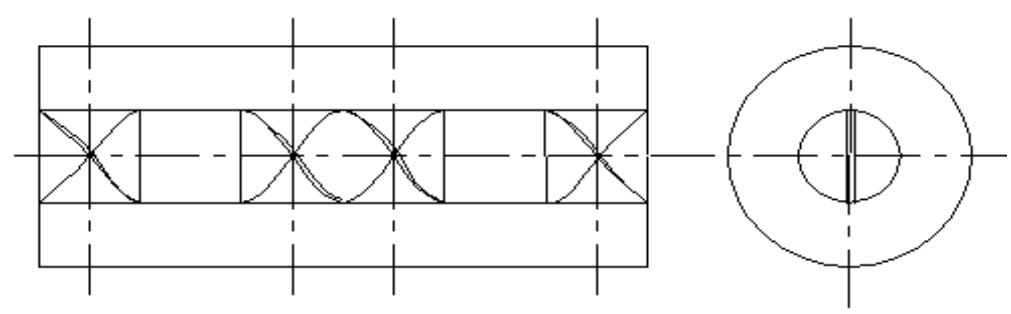

Figure 8 A schematic showing a tube surface with obstacles to generate a turbulent flow
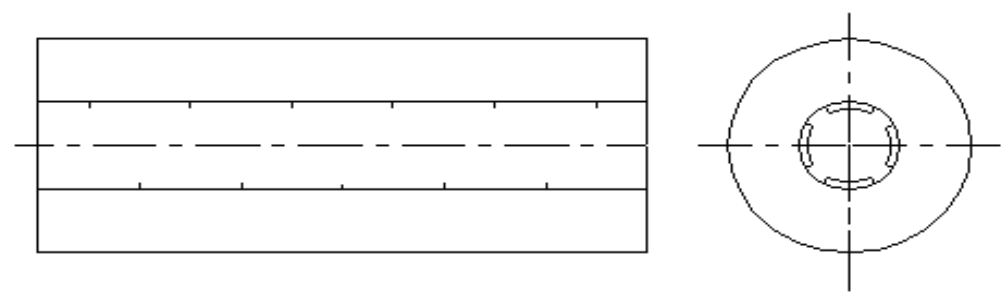

Figure 9 A schematic showing a helical coil placed inside the tube
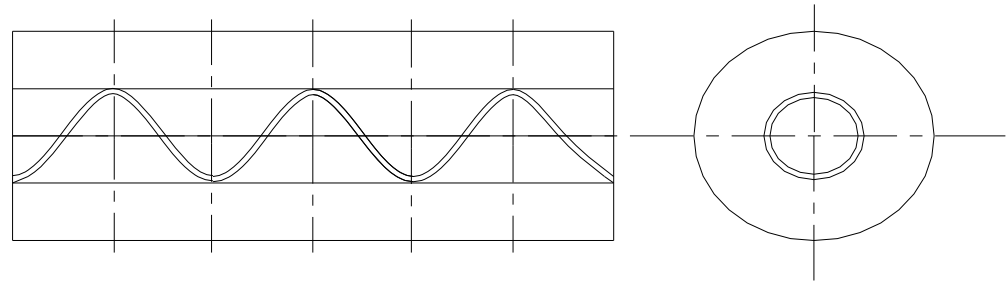
In this study, it was decided to use a passive method for heat transfer enhancement particularly due to its simplicity and low implementation cost. After evaluating several possible methods, it was decided that the use of twisted-tape inserts would be suitable as these can increase the convection coefficient by introducing swirl into the fluid flow. A twisted-tape consists of a thin strip that is periodically twisted through $360^{\circ}$ and also it can be designed and fabricated quite easily and economically. Here, the introduction of a tangential velocity component increases the speed of the flow, particularly near the tube wall. Therefore, twisted-tape inserts would be an economical, simple and highly efficient way of adding swirl to the fluid flow.

The technology of the twisted-tape inserts has been widely used in various industrial applications (Manglik and Bergles, 1993a, 1993b; Duplessis and Kroeger, 1983) and solar water heater systems (Kumar and Prasad, 2000). Inserting of twisted-tapes into a tube is a simple and economical passive method for enhancing the convective heat transfer by introducing swirl into the bulk flow and by disrupting the boundary layer at the tube surface due to the repeated changes in the surface geometry. Such twisted-tape inserts can induce turbulent and swirl motion (i.e., a superimposed vortex motion) leading to a thinner boundary layer and hence resulting in a high heat transfer coefficient and Nusselt number due to the recurrent changes in the geometry of the twisted-tape. The pressure drop in the tube flow may increase with the twisted-tape inserts while an enhancement of the rate of heat transfer is achieved. However, this technique has been widely used particularly in compact heat exchangers due to the low cost and easy settingup. Moreover, numerous previous work has focused on the heat transfer enhancement and pressure drop (Hong and Bergles, 1976; Eiamsa-ard et al., 2004a; Lepina and Bergles, 1969; Marner and Bergles, 1978; Yadav, 2009; Bharadwaj et al., 2009; Naphon, 2006; Saha and Bhunia, 2000; Hong et al., 2007; Vera-García et al., 2010); friction and heat transfer characteristics (Date, 1974; Date and Saha, 1990; Ray and Date, 2003; Jaisankar et al., 2009; Saha et al., 2001; Eiamsa-ard et al., 2009b, 2010); fraction factor and Nusselt number (Duplessis and Kroeger, 1983; Eiamsa-ard et al., 2009a, 2009b; Lin and Wang, 2009); effects of the geometry on heat transfer rate (Saha et al., 1989; Al-Fahed et al., 1998; Eiamsa-ard et al., 2009c, 2012; Liao and Xin, 2000; Kurtbaş et al., 2007; Sarada et al., 2010; Khalil et al., 2010; Zohir et al., 2011; Duangthongsuk and Wongwises, 2013); and thermo hydraulic performance (Suresh et al., 2003; Saha and Dutta, 2001) relating to twisted-tape inserts in heat exchangers. Furthermore, comprehensive review studies on the twisted-tape inserts with different geometrical arrangements (Kumar and Murugesan, 2012), methods of enhancing of heat transfer with swirl generators (Kumbhar and Sane, 2010) and also possible techniques in heat transfer augmentation (Siddique et al., 2010; Dewan et al., 2004; Gupta and Uniyal, 2012; Nagayach and Agrawal, 2012; Ganorkar and Kriplani, 2011; Stone and Vanka, 1996) can be found in the literature.

\subsection{Swirl into shell or tube flow?}

If it is required to add the swirl into the fluid flow inside the shell, a special type of tape and some other modifications may be required. In fact, this would be a difficult task as a number of tubes are usually placed inside the shell. To add the swirl into the fluid flow inside the tubes, a simple tape is sufficient and no additional modifications will be 
required. The typical velocity profiles with and without swirl inside a one shell pass and one tube pass counter flow heat exchanger are shown in Figure 10.

Figure 10 Typical velocity profiles before and after adding the swirl into the shell and tube flows (see online version for colours)

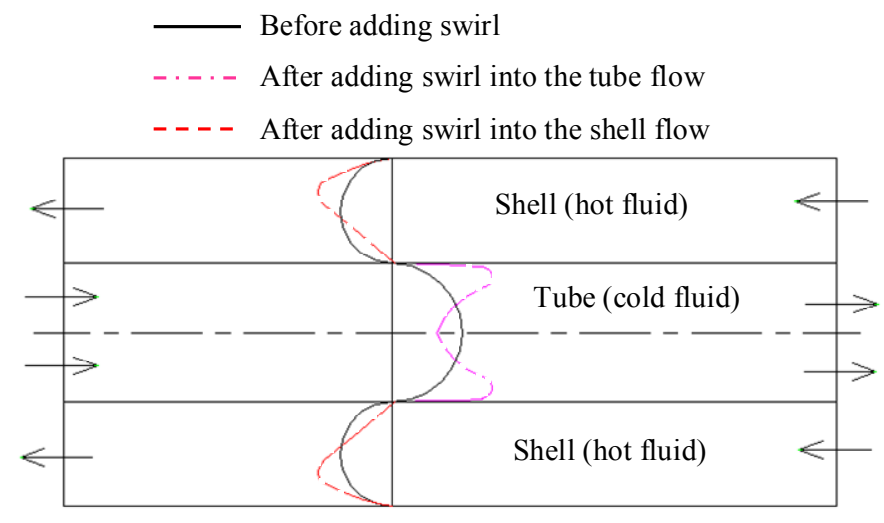

As the swirl is added, the amount of the water which flows near the wall will increase. As shown in Figure 10, the velocity profile of the flowing fluid would provide enhancing effects on the rate of heat transfer in the tube flow than the shell flow after adding swirl. Therefore, the addition of swirl into the tube flow/s would be an easy, economical and efficient approach than the addition of swirl into the fluid flow inside the shell.

\section{Experimental study}

In this study, a shell-and-tube heat exchanger with the following specifications was considered for the experimental calculations:

- one shell pass and one tube pass counter flow heat exchanger

- $\quad$ mild steel shell (inner diameter $=45 \mathrm{~mm}$ )

- $\quad$ inner copper tube (inner diameter $=25 \mathrm{~mm}$ )

- aluminium twisted-tape $\left(\mathrm{p}_{\mathrm{i}}=80 \mathrm{~mm}, \mathrm{Y}=3.2\right)$

- cold water as the cold fluid

- hot water as the hot fluid

Figure 11 Specifications of the selected twisted-tape

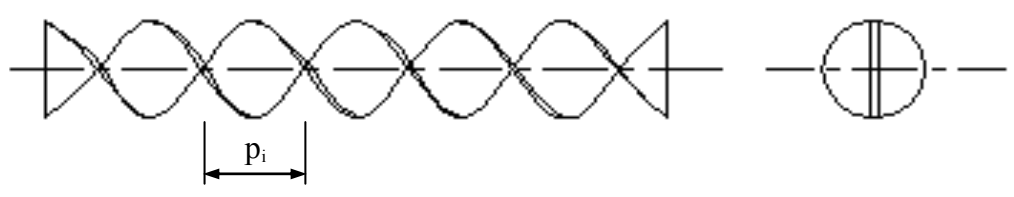




\section{Specific data}

For a twisted-tape (Eiamsa-ard et al., 2004b):

$$
\begin{aligned}
& \text { for } 5,000<\operatorname{Re}<43,000,3.18<Y<\infty \\
& Y=\text { twisted-ratio }=\text { half of the pitch/diameter }=p_{i} / d
\end{aligned}
$$

Flow conditions based on the Reynolds number (Re) (Incropera and Dewitt, 2002; Laminar and Turbulent Flows in Pipes):

laminar flow: $\operatorname{Re}<2,000$

transitional flow: $2,000<R e<4,000$

turbulent flow: $\operatorname{Re}>4,000$.

Dittus-Boelter correlation which represents the relationship between the Nusselt number $(\mathrm{Nu})$, Reynolds number and Prandtl number $(\mathrm{Pr})$ (Incropera and Dewitt, 2002):

$$
\begin{aligned}
& N u=0.023 \times \operatorname{Re}^{4 / 5} \times \operatorname{Pr}^{0.4} \text { (for the tube flow which is a turbulent flow) } \\
& N u=0.023 \times \operatorname{Re}^{4 / 5} \times \operatorname{Pr}^{1 / 3} \text { (for the annulus flow which is a transitional flow) }
\end{aligned}
$$

where

$$
\begin{aligned}
& N u=(h \times D) / k \\
& \operatorname{Pr}=\left(C_{p} \times \mu\right) / k \\
& \operatorname{Re}=(\rho \times V \times D) / \mu
\end{aligned}
$$

Usually, Dittus-Boelter correlation is valid for the conditions: $0.6 \leq \operatorname{Pr} \leq 160$, $R e \geq 10,000, L / D \geq 10$. However, in practice it is used even when the flow is in transition between laminar and turbulent conditions due to the lack of better correlations (Subramanian, 2007). For the natural convection, $N u$ is a function of a Grashof $(G r)$ and Reynolds numbers while it is a function of Reynolds and Prandtl numbers for the forced convection.

\subsection{Calculations}

\subsubsection{Calculation of the required length of the heat exchanger without the addition of swirl}

\section{Assumptions}

1 Negligible heat losses to the surroundings.

2 Negligible kinetic and potential energy changes.

3 Constant properties.

4 Negligible tube wall thermal resistance and fouling factors.

5 Fully developed conditions for the cold and hot fluid flows. 
6 Heat transfer rate through the $\mathrm{Cu}$ tube can be neglected.

\section{Problem specifications}

- Concentric flow, concentric tube heat exchanger.

- The performance of the inner tube (cold fluid).

$d=25 \mathrm{~mm}, m_{c}=0.30 \mathrm{~kg} . \mathrm{s}^{-1}$.

- The performance of the outer annulus/shell (hot fluid).

$D=45 \mathrm{~mm}, m_{h}=0.05 \mathrm{~kg} \cdot \mathrm{s}^{-1}$.

- Hot fluid inlet temperature, $T_{h, i}=100^{\circ} \mathrm{C}$.

- Hot fluid outlet temperature, $T_{h, o}=60^{\circ} \mathrm{C}$.

- Cold fluid inlet temperature, $T_{c, i}=30^{\circ} \mathrm{C}$.

- Cold fluid outlet temperature, $T_{c, o}=40^{\circ} \mathrm{C}$.

Figure 12 Model of the heat exchanger with the corresponding temperature-distance diagram
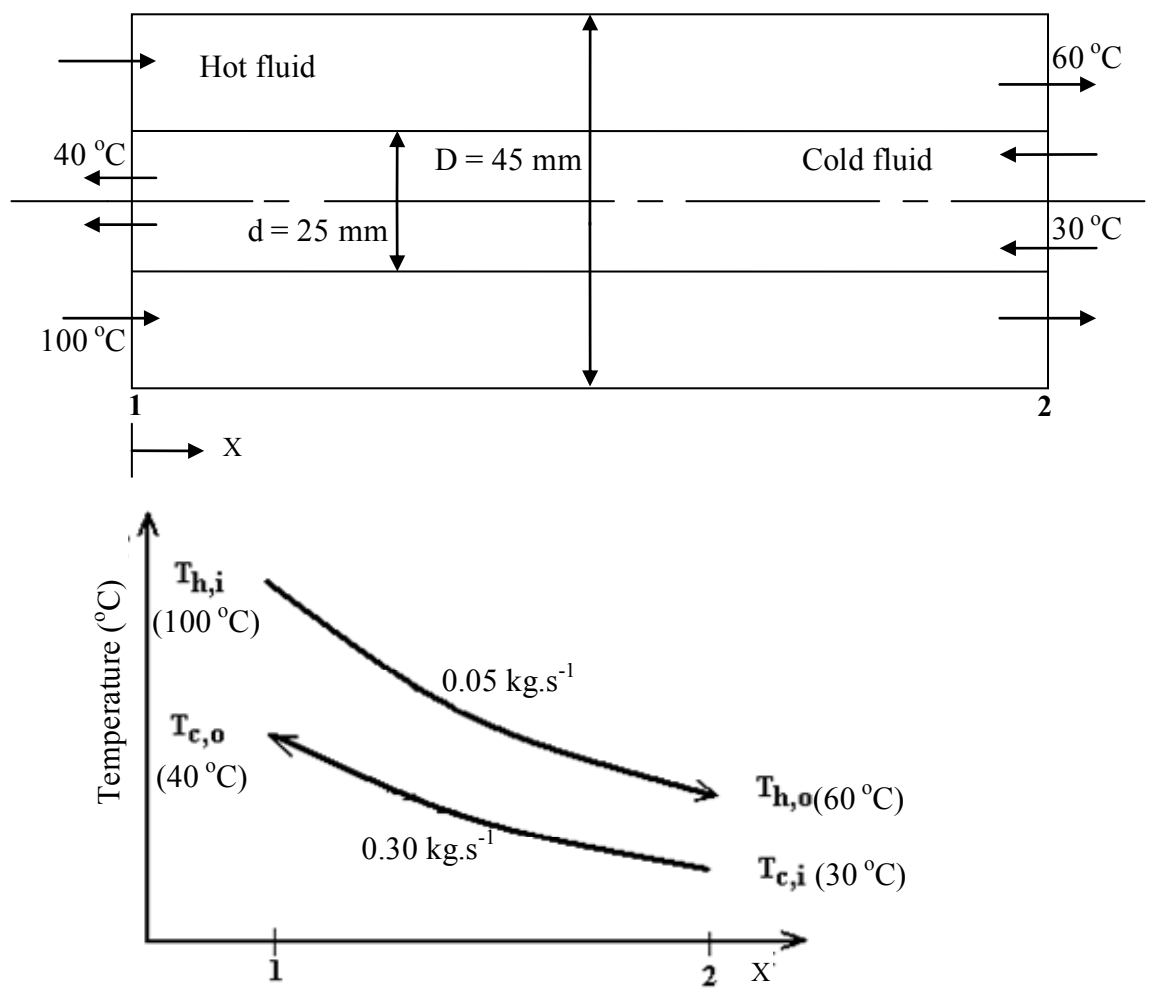

The average values of the temperature of the hot and cold fluids were considered for the calculations. 
Properties of the hot fluid (from property tables for the average temperature of the hot water) (Incropera and Dewitt, 2002):

$$
\begin{aligned}
& T_{h}=80^{\circ} \mathrm{C}=353 \mathrm{~K} \\
& C_{p}=4.197 \mathrm{~kJ} \cdot \mathrm{kg}^{-1} \cdot \mathrm{K}^{-1} \\
& P_{r}=2.2 \\
& \mu=351.8 \times 10^{-6} \mathrm{~Pa} . \mathrm{s} \\
& k=0.6698 \mathrm{~W} \cdot \mathrm{m}^{-1} \cdot \mathrm{k}^{-1}
\end{aligned}
$$

Properties of the cold fluid (from property tables for the average temperature of the cold water) (Incropera and Dewitt, 2002):

$$
\begin{aligned}
& T_{h}=35^{\circ} \mathrm{C}=308 \mathrm{~K} \\
& C_{p}=4.178 \mathrm{~kJ} \cdot \mathrm{kg}^{-1} \cdot \mathrm{K}^{-1} \\
& P_{r}=4.852 \\
& \mu=724.6 \times 10^{-6} \mathrm{~Pa} . \mathrm{s} \\
& k=0.628 \mathrm{~W} \cdot \mathrm{m}^{-1} \cdot \mathrm{k}^{-1}
\end{aligned}
$$

The required heat transfer rate, $q$, (i.e., to remove the heat from the hot fluid to reach the specified outlet temperature) can be obtained from the overall energy balance of the hot fluid:

$$
\begin{aligned}
& q=m_{h} \times C_{p, h} \times\left(T_{h, i}-T_{h, o}\right) \\
& q=0.05 \times 4,197.4 \times(100-60) \\
& q=8,395 \mathrm{~W}
\end{aligned}
$$

The outlet temperature of the cold fluid should be:

$$
\begin{aligned}
T_{c, o} & =q /\left(m_{c} \times C_{p, c}\right)+T_{c, i} \\
& =(8,395 /(0.3 \times 4,178))+30 \\
& =37^{\circ} \mathrm{C} \\
& \approx 40^{\circ} \mathrm{C}
\end{aligned}
$$

Then, the required length $(L)$ of the heat exchanger can be obtained from equation (3).

$$
q=U \times A \times \Delta T_{l m}
$$

where

$$
A=\pi \times d \times L
$$

$\Delta T_{l m}=\log$ mean temperature difference

$$
\begin{aligned}
\Delta T_{l m} & =\frac{\left(T_{h, i}-T_{c, o}\right)-\left(T_{h, o}-T_{c, i}\right)}{\ln \left(\left(T_{h, i}-T_{c, o}\right) /\left(T_{h, o}-T_{c, i}\right)\right)} \\
& =\frac{(100-40)-(60-30)}{\ln ((100-40) /(60-30))} \\
& =43^{\circ} \mathrm{C}
\end{aligned}
$$


The overall heat transfer coefficient is given by equation (4):

$$
U=\frac{1}{\left(1 / h_{i}\right)+\left(1 / h_{o}\right)}
$$

For the cold water flow through the tube:

$$
\begin{aligned}
\operatorname{Re} & =\frac{4 \times m_{c}}{\pi \times d \times \mu} \\
& =\frac{4 \times 0.3}{\pi \times 0.025 \times 724.6 \times 10^{-6}} \\
& =21,086
\end{aligned}
$$

Accordingly, the fluid flow inside the tube is turbulent and hence the Nusselt number is:

$$
\begin{aligned}
N u & =0.023 \times R e^{4 / 5} \times \operatorname{Pr}^{0.4} \\
& =0.023 \times 21,086^{4 / 5} \times 4.852^{0.4} \\
& =125
\end{aligned}
$$

Hence, the heat transfer coefficient is:

$$
\begin{aligned}
h_{i} & =(N u \times k) / D_{h} \\
& =\frac{(125 \times 0.628)}{0.025} \\
& =3,140 \mathrm{~W} \cdot \mathrm{m}^{-2} \cdot \mathrm{K}^{-1}
\end{aligned}
$$

For the flow of hot water through the annulus, the hydraulic diameter is:

$$
\begin{aligned}
D_{h} & =D-d \\
& =0.02
\end{aligned}
$$

And the Reynolds number is:

$$
\begin{aligned}
R e & =\frac{\rho \times V \times D_{h}}{\mu} \\
R e & =\frac{\rho \times(D-d) \times m_{h}}{\mu \times \rho \times \pi \times\left(D^{2}-d^{2}\right) / 4} \\
& =\frac{4 \times m_{h}}{\pi \times(D+d) \times \mu} \\
& =\frac{(4 \times 0.05)}{\pi \times(0.045+0.025) \times 351.8 \times 10^{-6}} \\
& =2,585
\end{aligned}
$$

The annulus flow is therefore transitional and hence the Nusselt number for a transitional flow is given by equation (9):

$$
\begin{aligned}
N u & =0.683 \times \operatorname{Re}^{0.557} \times \operatorname{Pr}^{1 / 3} \\
& =0.683 \times 2,585^{0.557} \times 2.2^{1 / 3} \\
& =71
\end{aligned}
$$


Hence

$$
\begin{aligned}
h_{o} & =(N u \times k) / D_{h} \\
& =\frac{(71 \times 0.6698)}{0.02} \\
& =2,378 \mathrm{~W} \cdot \mathrm{m}^{-2} \cdot \mathrm{K}^{-1}
\end{aligned}
$$

The overall convection coefficient is:

$$
\begin{aligned}
U & =\frac{1}{(1 / 3,140)+(1 / 2,378)} \\
& =1,353 \mathrm{~W} \cdot \mathrm{m}^{-2} \cdot \mathrm{K}^{-1}
\end{aligned}
$$

Therefore, the required length of a plain pipe is:

$$
\begin{aligned}
L & =\frac{q}{U \times \pi \times d \times \Delta T_{l m}} \\
& =\frac{8,395}{(1,353 \times \pi \times 0.025 \times 43.26)} \\
& =1.826 \mathrm{~m}
\end{aligned}
$$

The required length of a plain pipe (i.e., hence the length of the heat exchanger) to obtain the desired output temperature of the hot fluid is $1.826 \mathrm{~m}$. Moreover, the hot side convection coefficient $\left(h_{o}\right)$ controls the rate of heat transfer between the two fluids, and a low value of $h_{o}$ is responsible for a large value of the pipe length.

\subsubsection{Calculation of the required length of the heat exchanger with the addition of swirl}

Usually, the Nusselt number will increase with the addition of swirl to the fluid flow (i.e., with twisted-tape inserts). The rate of increase of the Nusselt number is dependent upon the regular spacing of the twisted-tape (e.g., $0.0 \mathrm{~L}, 0.1 \mathrm{~L}, 0.2 \mathrm{~L}$ etc.). The relationship between the Nusselt number and the Reynolds number of a fluid flow inside a circular pipe with a twisted-tape is shown in Figure 13 (Eiamsa-ard et al., 2004b) and this information was used for the calculations of this study.

The placement of a twisted-tape across a fluid flow causes to increase the swirl of the flow and also the pressure gradient in the radial direction. Moreover, the boundary layer along the tube wall would become thinner with the increase of radial swirl and pressure which leads to increase the rate of heat transfer through the fluid. Likewise, the addition swirl causes the flow to become turbulent and this leads to achieve a better convection heat transfer. As shown in Figure 13, the effects of the twisted-tape inserts are lower at low Reynolds numbers due to the weak swirl and low flow velocity. In general, the Nusselt number increases with the Reynolds number and some of the corresponding values illustrated in Figure 13 are given in Table 1. 
Figure 13 Relationship between the Nusselt number and Reynolds number for a plain tube and a plain tube with twisted-tape inserts

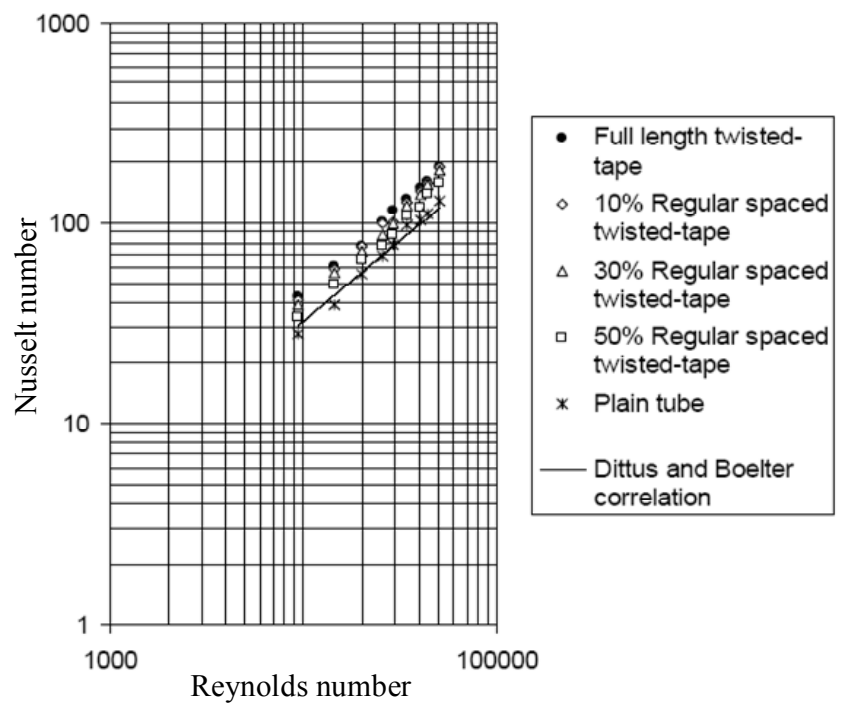

Source: Eiamsa-ard et al. (2004b)

Table 1 Nusselt number vs. Reynolds number with various regular spaced twisted-tape inserts

\begin{tabular}{lccccc}
\hline $\begin{array}{l}\text { Reynolds } \\
\begin{array}{l}\text { number } \\
\left(\times 10^{4}\right)\end{array}\end{array}$ & Plain tube & $\begin{array}{c}\text { O.5L regular } \\
\text { spaced } \\
\text { twisted-tape }\end{array}$ & $\begin{array}{c}\text { O.3L regular } \\
\text { spaced } \\
\text { twisted-tape }\end{array}$ & $\begin{array}{c}\text { 0.1L regular } \\
\text { spaced } \\
\text { twisted-tape }\end{array}$ & $\begin{array}{c}\text { Full-length } \\
\text { spaced } \\
\text { twisted-tape }\end{array}$ \\
\hline 0.95 & 28 & 35 & 38 & 40 & 43 \\
1.50 & 40 & 50 & 56 & 60 & 61 \\
2.00 & 56 & 68 & 71 & 78 & 79 \\
$\mathbf{2 . 1 0 8 6}$ & $\mathbf{5 8 . 3 5}$ & $\mathbf{6 9 . 8 1}$ & $\mathbf{7 3 . 7 2}$ & $\mathbf{8 1 . 9 8}$ & $\mathbf{8 4 . 6 1}$ \\
2.60 & 69 & 78 & 86 & 100 & 110 \\
3.00 & 79 & 88 & 98 & 105 & 130 \\
3.50 & 98 & 120 & 130 & 140 & 150 \\
4.00 & 105 & 128 & 150 & 155 & 160 \\
4.50 & 125 & 155 & 160 & 165 & 170 \\
5.00 & 140 & 170 & 190 & 195 & 198 \\
\hline
\end{tabular}

Source: Eiamsa-ard et al. (2004b)

For this study, a swirl generator (i.e., a twisted-tape) was introduced into the fluid flow inside the tube of the heat exchanger and the corresponding Reynolds number is 21,086 (the corresponding values in Table 1 are shown in bold). 
The procedure of determining the required pipe length with a $0.5 \mathrm{~L}$ regular spaced twisted-tape is discussed below:

$$
\begin{aligned}
\text { Percentage change of the Nusselt number } & =\frac{(69.81-58.35)}{58.35} \times 100 \% \\
& =19.63 \%
\end{aligned}
$$

New Nusselt number for the cold fluid flow $=125 \times(119.63 / 100)$

$$
=149.5
$$

Hence, the heat transfer coefficient is:

$$
\begin{aligned}
h i & =(N u \times k) / D_{h} \\
& =\frac{(149.5 \times 0.628)}{0.025} \\
& =3,755 \mathrm{~W} \cdot \mathrm{m}^{-2} \cdot \mathrm{K}^{-1}
\end{aligned}
$$

As there is no any change to the hot fluid flow inside the annulus (i.e., because a twist-tape was inserted only inside the tube), $h_{o}$ remains unchanged. Therefore, the overall convention heat transfer coefficient is:

$$
\begin{aligned}
U & =\frac{1}{(1 / 3,755)+(1 / 2,378)} \\
& =1,456 \mathrm{~W} \cdot \mathrm{m}^{-2} \cdot \mathrm{K}^{-1}
\end{aligned}
$$

Hence, the required new pipe length is:

$$
\begin{aligned}
L & =\frac{q}{U \times \pi \times d \times \Delta T_{l m}} \\
& =\frac{3,395}{1,456 \times \pi \times 0.025 \times 43.26} \\
& =1.697 \mathrm{~m}
\end{aligned}
$$

By following the same procedure, the required lengths of the pipe with $0.3 \mathrm{~L}, 0.1 \mathrm{~L}$ and full-length regular spaced twisted-tapes were calculated and the corresponding values are $1.662 \mathrm{~m}, 1.598 \mathrm{~m}$ and $1.583 \mathrm{~m}$, respectively.

\subsection{Increase in the pressure drop due to the addition of swirl}

There is an increase in the axial pressure drop (pressure is constant along the axial distance) after adding the swirl into the tube flow and this varies with the Reynolds number as shown in Figure 14. The corresponding pressure drops due to the twisted-tape inserts were calculated based on the information given in Figure 14 and these details are given in Table 2. 
Figure 14 Relationship between the pressure drop and Reynolds number for a tube with and without twisted-tape inserts

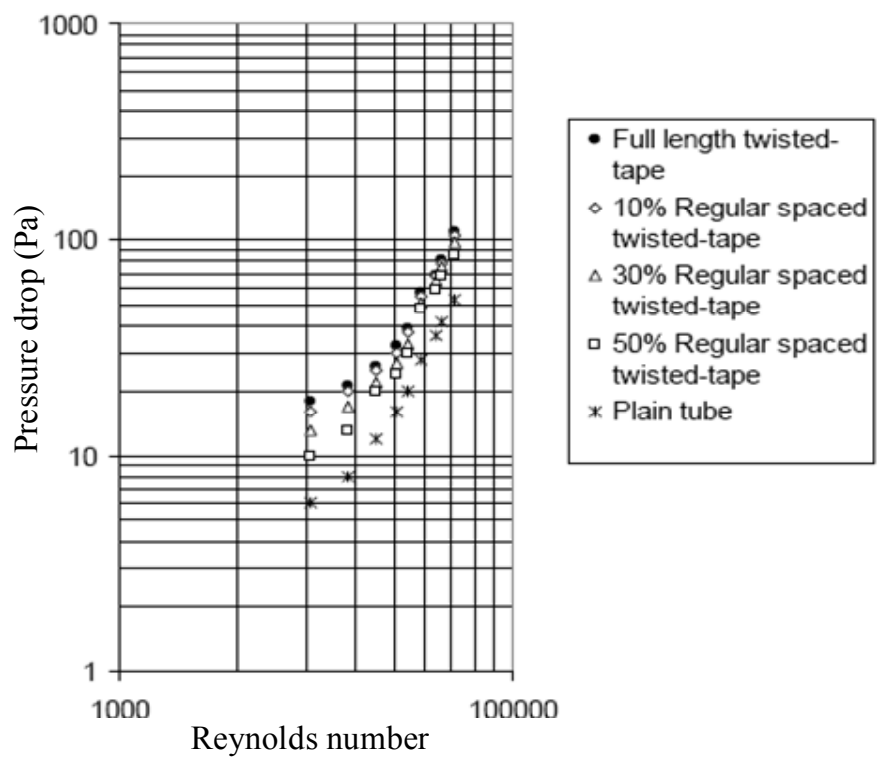

Source: Eiamsa-ard et al. (2004b)

Table 2 Pressure drop vs. Reynolds number after inserting the twisted-tapes with various regular spacing

\begin{tabular}{lccccc}
\hline & \multicolumn{5}{c}{ Pressure drop $(\mathrm{Pa})$} \\
\cline { 2 - 6 } $\begin{array}{l}\text { Reynolds } \\
\left(\times 10^{-4}\right)\end{array}$ & Plain tube & $\begin{array}{c}\text { 0.5L regular } \\
\text { spaced } \\
\text { twisted-tape }\end{array}$ & $\begin{array}{c}\text { 0.3L regular } \\
\text { spaced } \\
\text { twisted-tape }\end{array}$ & $\begin{array}{c}\text { 0.1L regular } \\
\text { spaced } \\
\text { twisted-tape }\end{array}$ & $\begin{array}{c}\text { Full-length } \\
\text { spaced } \\
\text { twisted-tape }\end{array}$ \\
\hline 0.95 & 6 & 10 & 14 & 17 & 18 \\
1.50 & 8 & 15 & 18 & 20 & 21 \\
2.00 & 13 & 20 & 21 & 22 & 22.5 \\
$\mathbf{2 . 1 0 8 6}$ & $\mathbf{1 4 . 1}$ & $\mathbf{2 1 . 1}$ & $\mathbf{2 2 . 3}$ & $\mathbf{2 2 . 4}$ & $\mathbf{2 2 . 8}$ \\
\hline
\end{tabular}

For this study, the Reynolds number of the tube flow is 21,086 and the relevant pressure drop values are shown in bold in Table 2 .

\section{Designing of a prototype of the heat exchanger}

A prototype shell-and-tube heat exchanger was fabricated (a photograph is shown in Figure 15) based on the above calculations to experimentally investigate the improvements to the heat transfer and other corresponding issues. 
Figure 15 The fabricated prototype shell-and-tube heat exchanger (see online version for colours)

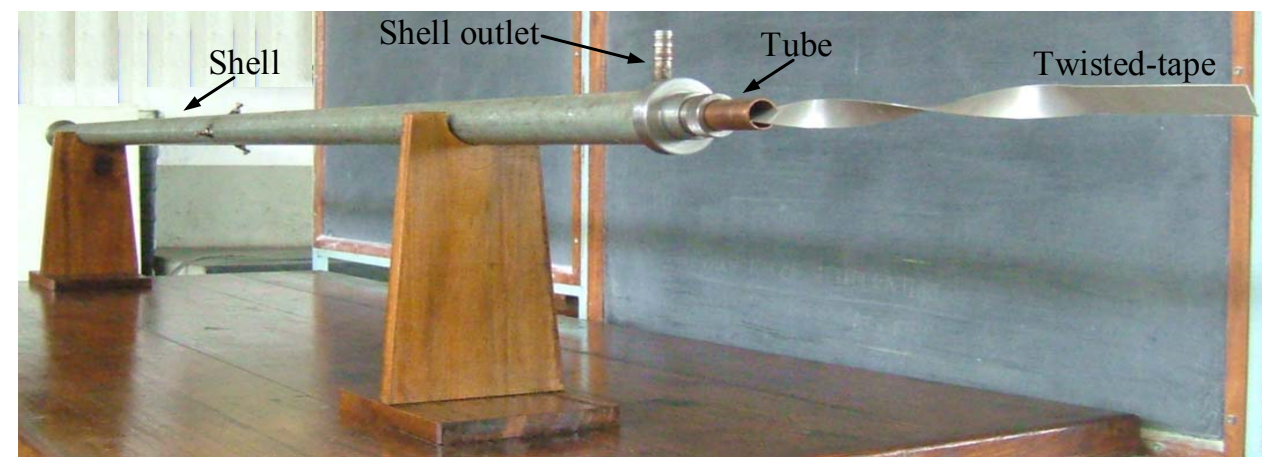

This will be used for further studies on the benefits, limitations and possible drawbacks of the addition of swirl to the fluid flow in the tube by inserting twisted-tapes with various regular spacing, geometries, etc.

\section{Cost evaluation for the fabrication of the heat exchanger with and without swirl}

A comparison of the fabrication cost of the heat exchanger with and without swirl is presented in the followings. The labour cost for fabrication was considered as the same in both cases. All the prices are provided in Sri Lankan rupees (Rs).

Materials used for the fabrication:

- $\quad$ shell - mild steel pipe

- $\quad$ tube-copper pipe

- twisted-tape - aluminium

- mild steel sockets as sealing components

- $\quad$ Rubber ' $\mathrm{O}$ ' rings for sealing purposes.

Table 3 Material prices in the market (Sri Lanka)

\begin{tabular}{|c|c|c|c|c|c|c|}
\hline \multirow{2}{*}{ No. } & \multirow{2}{*}{ Material } & \multirow{2}{*}{ Size } & \multirow{2}{*}{$\begin{array}{l}\text { Diameter } \\
(\mathrm{mm})\end{array}$} & \multicolumn{2}{|c|}{ Thickness (mm) } & \multirow{2}{*}{ Price $(R s)$} \\
\hline & & & & Wall & Sheet & \\
\hline 1 & Aluminium sheet & $8 \times 4 \mathrm{ft}^{2}$ & - & - & 1.2 & 4,000 \\
\hline 2 & Copper tube & $19 \mathrm{ft}$ & 25 & 1 & - & 4,500 \\
\hline 3 & GI pipe & $19 \mathrm{ft}$ & - & 2 & - & 2,000 \\
\hline 4 & GI sheet & $8 \times 4 \mathrm{ft}^{2}$ & - & - & 2 & 4,850 \\
\hline 5 & GI pipe & $19 \mathrm{ft}$ & 12.7 & 2 & - & 700 \\
\hline 6 & Rubber ' $\mathrm{O}$ ' ring & - & (bore) 6 & - & - & 150 \\
\hline
\end{tabular}


Table 4 Material requirement without the addition of the swirl

\begin{tabular}{|c|c|c|c|c|c|}
\hline \multirow{2}{*}{ Material } & \multirow{2}{*}{$\begin{array}{l}\text { Required } \\
\text { size }\end{array}$} & \multirow{2}{*}{$\begin{array}{l}\text { Diameter } \\
\quad(\mathrm{mm})\end{array}$} & \multicolumn{2}{|c|}{ Thickness } & \multirow{2}{*}{$\operatorname{Cost}(R s$} \\
\hline & & & Wall & Sheet & \\
\hline Aluminium sheet & - & - & - & 1.2 & 0 \\
\hline Copper tube & $1.826 \mathrm{~m}$ & 25.0 & 1 & - & 1,420 \\
\hline GI pipe & $1.726 \mathrm{~m}$ & 45.0 & 2 & - & 596 \\
\hline $2 \times$ GI pipe socket & - & 49.0 & - & - & 300 \\
\hline $2 \times$ GI pipe socket & - & 30.0 & - & 2.0 & 250 \\
\hline GI pipe & $0.1 \mathrm{~m}$ & 12.7 & 2 & - & 15 \\
\hline Rubber 'O' ring & - & 25 & - & - & 150 \\
\hline Welding & & & & & 100 \\
\hline Labour cost & & & & & - \\
\hline Total cost & & & & & 2,831 \\
\hline
\end{tabular}

Table 5 Material requirement with the addition of the swirl

\begin{tabular}{|c|c|c|c|c|c|}
\hline \multirow{2}{*}{ Material } & \multirow{2}{*}{ Required size } & \multirow{2}{*}{$\begin{array}{c}\text { Diameter } \\
(\mathrm{mm})\end{array}$} & \multicolumn{2}{|c|}{ Thickness } & \multirow{2}{*}{$\operatorname{Cost}(R s$} \\
\hline & & & Wall & Sheet & \\
\hline Aluminium sheet & $24 \times 1670 \mathrm{~mm}^{2}$ & - & - & 1.2 & 54 \\
\hline Copper tube & $1.583 \mathrm{~m}$ & 25.0 & 1 & - & 1,250 \\
\hline GI pipe & $1.483 \mathrm{~m}$ & 45.0 & 2 & - & 520 \\
\hline $2 \times$ GI pipe socket & - & 49.0 & - & - & 300 \\
\hline $2 \times$ GI pipe socket & - & 30.0 & - & 2.0 & 250 \\
\hline GI pipe & $0.1 \mathrm{~m}$ & 12.7 & 2 & - & 15 \\
\hline Rubber ' $\mathrm{O}$ ' ring & - & 3.0 & - & - & 150 \\
\hline Welding & & & & & 100 \\
\hline Labour cost & & & & & - \\
\hline Total cost & & & & & 2,639 \\
\hline
\end{tabular}

As shown in Tables 4 and 5, the total fabrication cost of the heat exchanger has reduced by $6.8 \%$ with the addition of swirl. In fact, these calculations represent a shell-and-tube heat exchanger only with one tube, and the manufacturing cost should be further reduced for the heat exchangers with multiple tubes which are commonly used in the practical/industrial applications.

\section{Discussion}

The major objective of this research was to explore the improvement of the performance of a shell-and-tube heat exchanger with the addition of swirl. It was able to study the enhancement of the rate of heat transfer and the increase in the pressure drop with the addition of swirl. A counter flow shell-and-tube heat exchanger was considered for the case study. The mean Nusselt numbers relating to the annulus and tube fluid flows were estimated with reference to the Reynolds number (based on the published literature) with 
four different regular spaced twisted-tapes [i.e., with full-length $(0.0 \mathrm{~L}), 0.5 \mathrm{~L}, 0.3 \mathrm{~L}$ and $0.1 \mathrm{~L}$ regular spaced twisted-tape inserts].

\subsection{Improvements to the rate of heat transfer}

By placing a twisted-tape through the tube fluid flow, the Nusselt number can be increased and these increments are dependent upon the size of the regular spacing of the twisted-tape. The theoretical result shows that the smaller the regular spacing, the higher the Nusselt number. Moreover, the magnitude of increase of the Nusselt number increases as increasing the Reynolds number. In general, the twisted-tape inserts cause to add swirl to the flow while generating a pressure gradient in the radial direction. The boundary layer along the tube wall would become thinner with the increase of radial swirl due to the increasing turbulent behaviour of the flow and this would lead to increase the rate of heat transfer. According to the details shown in Table 6, it is clear that the rate of heat transfer increases as narrowing the regular spacing between twisted-tape inserts. The full-length twisted-tape insert $(\mathrm{S}=0.0 \mathrm{~L})$ gave the maximum rate of heat transfer and hence this offered the shortest pipe length to achieve the required rate of heat transfer between the cold and hot fluids.

Table 6 A comparison of parameters with and without swirl

\begin{tabular}{|c|c|c|c|c|c|}
\hline Parameter & Plain tube & $\begin{array}{l}\text { 0.5L regular } \\
\text { spaced } \\
\text { twisted-tape }\end{array}$ & $\begin{array}{l}0.3 L \text { regular } \\
\text { spaced } \\
\text { twisted-tape }\end{array}$ & $\begin{array}{l}0.1 L \text { regular } \\
\text { spaced } \\
\text { twisted-tape }\end{array}$ & $\begin{array}{l}0.0 \text { regular } \\
\text { spaced } \\
\text { twisted-tape }\end{array}$ \\
\hline $\begin{array}{l}\text { Overall heat } \\
\text { transfer coefficient } \\
\left(\mathrm{W} \cdot \mathrm{m}^{-2} \cdot \mathrm{K}^{-1}\right)\end{array}$ & 1,340 & 1,456 & 1,487 & 1,546 & 1,561 \\
\hline $\begin{array}{l}N u \text { number in the } \\
\text { tube flow }\end{array}$ & 125 & 149.5 & 157.9 & 176 & 181 \\
\hline $\begin{array}{l}\text { Required length of } \\
\text { the tube }(\mathrm{m})\end{array}$ & 1.826 & 1.697 & 1.662 & 1.598 & 1.583 \\
\hline $\begin{array}{l}\text { Reduction of the } \\
\text { length of the pipe } \\
\text { (m) }\end{array}$ & - & 0.129 & 0.164 & 0.228 & 0.243 \\
\hline $\begin{array}{l}\text { Percentage of } \\
\text { reduction of the } \\
\text { required length of } \\
\text { the pipe }(\%)\end{array}$ & - & 7.06 & 8.98 & 12.49 & 13.31 \\
\hline Pressure drop $(\mathrm{Pa})$ & 14.1 & 21.1 & 22.3 & 22.4 & 22.8 \\
\hline
\end{tabular}

\subsection{Pressure drop}

As was expected, the pressure drop increased with the twisted-tape inserts. According to the details shown in Table 6, the lower the space between the tapes, the higher the pressure drop. Obviously, the fluid pumping power within the tube should go up to maintain the required flow rate due to the increase of the pressure drop. However, the increase of the pressure drop (and hence the additional pumping power) may be compromised by the amount of reduction of the size/space of the heat exchanger for some particular applications. Moreover, the pressure drop may be reduced by reducing the 
thickness of the twisted-tape and more details relating to the pressure drop will be explored under future work.

\subsection{Benefits of the addition of swirl}

The information relating to a comparison of a number of parameters with and without swirl is given in Table 6. Furthermore, a comparison of parameters between a plain tube and the same tube with a full-length twisted tape (i.e., the situation of which the highest rate of heat transfer was achieved) is given in Table 7.

Table 7 A comparison of parameters of a plain tube and the same tube with a full-length twisted tape

\begin{tabular}{lccc}
\hline Parameter & Plain tube & $\begin{array}{c}\text { With a full length } \\
\text { twisted-tape } \\
\text { inside the pipe }\end{array}$ & $\begin{array}{c}\text { Percentage of } \\
\text { reduction or } \\
\text { increment (\%) }\end{array}$ \\
\hline Overall heat transfer coefficient & $1,340 \mathrm{~W} \cdot \mathrm{m}^{-2} \cdot \mathrm{K}^{-1}$ & $1,561 \mathrm{~W} \cdot \mathrm{m}^{-2} \cdot \mathrm{K}^{-1}$ & 16.5 \\
$\mathrm{Nu}$ number in the tube flow & 125 & 181 & 44.8 \\
Pressure drop & $14.1 \mathrm{~Pa}$ & $22.8 \mathrm{~Pa}$ & 61.7 \\
Required length of the tube & $1.826 \mathrm{~m}$ & $1.583 \mathrm{~m}$ & 13.3 \\
Total cost & Rs. 2,831 & Rs. 2,639 & 6.8 \\
\hline
\end{tabular}

The results show that the rate of heat transfer has increased by a percentage of 16.5 with a full-length twisted-tape insert leading to a $13.3 \%$ reduction of the required length of the heat exchanger. Therefore, it is clear that the inserting of twisted-tapes is an effective way to improve the performance of heat exchangers and hence to reduce their size (i.e., heat exchangers which are compact in size) to perform a particular task. Moreover, the fabrication cost of the heat exchanger has reduced by $6.8 \%$ with the addition of swirl to the fluid flow inside the tube. In fact, the case study presented in this work considered a heat exchanger with a single tube. However, the shell-and-tube heat exchangers which are commonly used in industrial applications are included a number of tubes inside the shell. Therefore, the addition of swirl to the tube flow of a heat exchanger which has multiple tubes may provide further improvements of the rate of heat transfer and further reductions to the fabrication cost.

The design and fabrication of twisted-tapes are quite simple and also there is no need of any additional modification to the tube for inserting these tapes. Therefore, the inserting of twisted-tapes is a highly compatible technique for industrial applications. However, one of the disadvantages of this technique is that the increase of the pressure drop which may lead to demand more power to pump the fluid inside the tube/s. Therefore, it is better to further study on the increase of the cost factors due to the increase of the required power for pumping and this will be explored in the next stage of this study. Therefore, some of the major factors which should be taken into account as the addition of swirl for designing of compact heat exchangers are:

- the space requirements/limitations to place/position the heat exchanger

- simplicity, effectiveness and the access requirements of the swirl generator/s

- design and fabrication cost of the heat exchanger with and without swirl 
- the level of increase of the pressure drop with the addition of swirl

- the level of increase of the required pumping power with the addition of swirl.

Overall, it seems that the inserting of twisted-tapes is a simple, cost effective and efficient technique for enhancing the rate heat transfer and hence to design compact heat exchangers.

\section{Conclusions}

This study was mainly focused on investigating strategies to improve the performance of shell-and-tube heat exchangers by the addition of swirl. A number of possible methods were considered which can be used to add swirl into a fluid flow. Of these techniques, a twisted-tape insert was selected to use in this study. A case study was presented for calculating the increase of rate of heat transfer, the reduction of the required length of the tube and increase of the pressure drop with a number of twisted-tape inserts with different regular spacing. The results confirmed that the twisted-tape inserts are one of the simple and effective techniques to improve the rate of heat transfer without involving complex modifications to the typical design of shell-and-tube heat exchangers. A full-length twisted-tape gave the highest rate of heat transfer and hence the minimum tube length required to achieve the considered task. In general, it showed that the size of the heat exchanger can be reduced considerably by introducing swirl to the tube flow by inserting twisted-tapes and also the fabrication cost showed a reduction of around $6.8 \%$ for this particular case study. Conversely, the results showed that an increase in the pressure drop with the twisted-tape inserts where the full-length twisted-tape gave the maximum axial pressure drop inside the tube fluid flow. Therefore, the required power for pumping of fluid inside the tube should be increased due to the twisted-tape which is one of the drawbacks of this technique. Moreover, a model of shell-and-tube heat exchanger was designed and fabricated based on the case study considered. This will be used for further study about the effects of pressure drop on the pumping power required. Moreover, studies are underway to explore the effective and economical strategies to improve the rate of heat transfer which allows the design of compact heat exchangers.

\section{Acknowledgements}

Those who supported to this work with useful discussions and in setting-up equipment are greatly acknowledged.

\section{References}

Al-Fahed, S., Chamra, L.M. and Chakroun, W. (1998) 'Pressure drop and heat transfer comparison for both micro-fin tube and twisted-tape inserts in laminar flow', Experimental Thermal and Fluid Science, Vol. 18, No. 4, pp.323-333.

Bharadwaj, P., Khondge, A.D. and Date, A.W. (2009) 'Heat transfer and pressure drop in a spirally grooved tube with twisted tape insert', International Journal of Mass and Heat Transfer, Vol. 52, Nos. 7-8, pp.1938-1944. 
Chang, F. and Dhir, V.K. (1995) 'Mechanisms of heat transfer enhancement and slow decay of swirl in tubes using tangential injection', International Journal Heat Fluid Flow, Vol. 16, No. 2, pp.78-87.

Date, A.W. (1974) 'Prediction of fully developed flow in a tube containing a twisted tape', International Journal of Heat and Mass Transfer, Vol. 17, No. 8, pp.845-859.

Date, A.W. and Saha, S.K. (1990) 'Numerical prediction of laminar flow and heat transfer in a tube fitted with regularly spaced twisted-tape elements', International Journal of Heat and Fluid Flow, Vol. 11, No. 4, pp.346-354.

Dewan, A., Mahanta, P., Raju, K.S. and Kumar, P.S. (2004) 'Review of passive heat transfer augmentation techniques', Proceeding of the Institutions of Mechanical Engineers - Part A: Journal Power and Energy, Vol. 218, No. 7, pp.509-527.

Duangthongsuk, W. and Wongwises, S. (2013) 'An experimental investigation of the heat transfer and pressure drop characteristics of a circular tube fitted with rotating turbine-type swirl generators', Experimental Thermal and Fluid Science, Vol. 45, pp.8-15.

Duplessis, J.P. and Kroeger, D.G. (1983) 'Numerical prediction of laminar flow with heat transfer in tube with a twisted tape insert', Proceedings of the International Conference on Numerical Methods in Laminar and Turbulent Flow, pp.775-785.

Eiamsa-ard, S. and Promvonge, P. (2005) 'Enhancement of heat transfer in a tube with regularly-spaced helical tape swirl generators', Solar Energy, Vol. 78, No. 4, pp.483-484.

Eiamsa-ard, S., Thianpong, C. and Eiamsa-ard, P. (2009a) 'Turbulent heat transfer enhancement by counter/co-swirling flow in a tube fitted with twin twisted tapes', Experimental Thermal and Fluid Science, Vol. 34, No. 1, pp.53-62.

Eiamsa-ard, S., Thianpong, C. and Promvonge, P. (2004a) 'Experimental investigations of heat transfer and pressure drop characteristics of flow through circular tube fitted with regularly-spaced twisted tape', The Joint International Confernce on Sustainable Energy and Environment, Hua Hin, Thailand, pp.18-22.

Eiamsa-ard, S., Thianpong, C., Eiamsa-ard, P. and Promvonge, P. (2009b) 'Convective heat transfer in a circular tube with short-length twisted tape insert', International Communications in Heat and Mass Transfer, Vol. 36, No. 4, pp.365-371.

Eiamsa-ard, S., Thianpong, C., Promvonge, P. and Sripattanapipa, S. (2004b) 'Enhancement of heat transfer in a concentric tube heat exchanger with regular spaced twisted-tapes swirl generators', The Tenth Asian Congress of Fluid Mechanics, 17-21 May 2004, University of Peradeniya, Sri Lanka.

Eiamsa-ard, S., Wongcharee, K. and Sripattanapipat, S. (2009c) '3-D numerical simulation of swirling flow and convective heat transfer in a circular tube induced by means of loose-fit twisted tapes', International Communications in Heat and Mass Transfer, Vol. 36, No. 9, pp.947-955.

Eiamsa-ard, S., Wongcharee, K., Eiamsa-ard, P. and Thianpong, C. (2010) 'Heat transfer enhancement in a tube using delta-winglet twisted tape inserts', Applied Thermal Engineering, Vol. 30, No. 4, pp.310-318.

Eiamsa-ard, S., Yongsiri, K., Nanan, K. and Thianpong, C. (2012) 'Heat transfer augmentation by helically twisted tapes as swirl and turbulence promoters', Chemical Engineering and Processing, Vol. 60, pp.42-48.

Eryener, D. (2006) 'Thermoeconomic optimization of baffle spacing for shell and tube heat exchangers', Energy Conversion and Management, Vol. 47, Nos. 11-12, pp.1478-1489.

Ganorkar, A.B. and Kriplani, V.M. (2011) 'Review of heat transfer enhancement in different types of extended surfaces', International Journal of Engineering Science and Technology, Vol. 3, No. 4, pp.3304-3313.

Gupta, A. and Uniyal, M. (2012) 'Review of heat transfer augmentation through different passive intensifier methods', OSR Journal of Mechanical and Civil Engineering, Vol. 1, No. 4, pp.14-21. 
Hong, M., Deng, X., Huang, K. and Li, Z. (2007) 'Compound heat transfer enhancement of a converging-diverging tube with evenly spaced twisted-tapes', Chinese Journal of Chemical Engineering, Vol. 15, No. 6, pp.814-820.

Hong, S.W. and Bergles, A.E. (1976) 'Augmentation of laminar flow heat transfer in tubes by means of twisted-tape inserts', ASME Journal of Heat Transfer, Vol. 98, No. 2, pp.251-256.

Incropera, F.P. and Dewitt, D.P. (2002) Fundamentals of Heat and Mass Transfer, 5th ed., Chapter 8, pp.489-493, Chapter 11, pp.655-680, John Wiley and Sons Inc., New York.

Jaisankar, S., Radhakrishnan, T.K. and Sheeba, K.N. (2009) 'Experimental studies on heat transfer and friction factor characteristics of forced circulation solar water heater system fitted with helical twisted tapes', Solar Energy, Vol. 83, No. 11, pp.1943-1952.

James, R.W., Charles, E.W., Robert, E.W. and Gregory, R. (2001) Fundamentals of Momentum, Heat and Mass Transfer, 4th ed., 2001, Ch. 20, pp.312-333, John Wiley and Sons Inc., New York.

Khalil, A., Zohir, A.E. and Farid, A.M. (2010) 'Heat transfer characteristics and friction of turbulent swirling air flow through abrupt expansion', American Journal of Scientific and Industrial Research, Vol. 1, No. 2, pp.364-374.

Kumar, A. and Prasad, B.N. (2000) 'Investigation of twisted tape inserted solar water heaters-heat transfer, friction factor and thermal performance results', Renewable Energy, Vol. 19, No. 3, pp.379-398.

Kumar, C.N. and Murugesan, P. (2012) 'Review on twisted tapes heat transfer enhancement', International Journal of Scientific and Engineering Research, Vol. 3, No. 4, pp.1-9.

Kumbhar, D.G. and Sane, N.K. (2010) 'Heat transfer enhancement in a circular tube twisted with swirl generator: a review', Proceedings of the Third International Conference on Advances in Mechanical Engineering, 4-6 January, Gujarat, India, pp.188-192.

Kurtbaş, İ., Durmuş, A., Eren, H. and Turgut, E. (2007) 'Effect of propeller type swirl generators on the entropy generation and efficiency of heat exchangers', International Journal of Thermal Sciences, Vol. 46, No. 3, pp.300-307.

Laminar and Turbulent Flows in Pipes [online] http://www.cs.cdu.edu.au/homepages/jmitroy/ eng243/sect09.pdf (accessed 3 March 2013).

Lepina, R.F. and Bergles, A.E. (1969) 'Heat transfer and pressure drop in tape-generated swirl flow of single-phase water', ASME Journal of Heat Transfer, Vol. 91, No. 3, pp.434-442.

Liao, Q. and Xin, M.D. (2000) 'Augmentation of convective heat transfer inside tubes with three-dimensional internal extended surfaces and twisted-tape inserts', Chemical Engineering Journal, Vol. 78, Nos. 2-3, pp.95-105.

Lin, Z-M. and Wang, L-B. (2009) 'Convective heat transfer enhancement in a circular tube using twisted tape', ASME Journal of Heat Transfer, Vol. 131, No. 8, pp.81-91.

Manglik, R.M. and Bergles, A.E. (1993a) 'Heat transfer and pressure drop correlations for twisted-tape inserts in isothermal tubes, Part I. Laminar flows', ASME Journal of Heat Transfer, Vol. 115, No. 4, pp.881-889.

Manglik, R.M. and Bergles, A.E. (1993b) 'Heat transfer and pressure drop correlations for twisted-tape inserts in isothermal tubes: Part II - transition and turbulent flows', ASME Journal of Heat Transfer, Vol. 115, No. 4, pp.890-896.

Marner, W.J. and Bergles, A.E. (1978) 'Augmentation of tube side laminar flow heat transfer by means of twisted-tape inserts, static mixer inserts, and internally finned tubes', Heat Transfer, Proceedings of Sixth International Heat Transfer Conference, Washington, USA, Vol. 2, pp.583-588, Hemisphere Publishing.

Nagayach, N.K. and Agrawal, A.B. (2012) 'Review of heat transfer augmentation in circular and non-circular tube', International Journal of Engineering Research and Applications, Vol. 2, No. 5, pp.796-802. 
Naphon, P. (2006) 'Heat transfer and pressure drop in the horizontal double pipes with and without twisted tape insert', International Communications in Heat and Mass Transfer, Vol. 33, No. 2, pp.166-175.

Ray, S. and Date, A.W. (2003) 'Friction and heat transfer characteristics of flow through square duct with twisted tape insert', International Journal of Heat and Mass Transfer, Vol. 46, No. 5, pp.889-902.

Saha, S.K. and Bhunia, K. (2000) 'Heat transfer and pressure drop characteristics of varying pitch twisted-tape-generated laminar smooth swirl flow', in the Proceedings of Fourth ISHMTASME Heat and Mass Transfer Conference, India, pp.423-428.

Saha, S.K. and Dutta, A. (2001) 'Thermo-hydraulic study of laminar swirl flow through a circular tube fitted with twisted tapes', ASME Journal of Heat Transfer, Vol. 123, No. 3, pp.417-421.

Saha, S.K., Dutta, A. and Dhal, S.K. (2001) 'Friction and heat transfer characteristics of laminar swirl flow through a circular tube fitted with regularly spaced twisted-tape elements', International Journal of Mass and Heat Transfer, Vol. 44, No. 22, pp.4211-4223.

Saha, S.K., Gaitonde, U.N. and Date, A.W. (1989) 'Heat transfer and pressure drop characteristics of laminar flow in a circular tube fitted with regularly spaced twisted-tape elements', Experimental Thermal and Fluid Science, Vol. 2, No. 3, pp.310-322.

Sarada, S.N., Raju, A.V.S.R., Radha, K.K. and Sunder, L.S. (2010) 'Enhancement of heat transfer using varying width twisted tape inserts', International Journal of Engineering, Science and Technology, Vol. 2, No. 6, pp.107-118.

Siddique, M., Khaled, A-R.A., Abdulhafiz, N.I. and Boukhary, A.Y. (2010) 'Recent advances in heat transfer enhancements: a review report', International Journal of Chemical Engineering, Article ID 106461, 28 pages, doi:10.1155/2010/106461.

Stone, K. and Vanka, S.P. (1996) Review of Literature on Heat Transfer Enhancement in Compact Heat Exchangers, a report prepared by Air Conditioning and Refrigeration Center, University of Illinois, August [online] https://ideals.illinois.edu/bitstream/handle/2142/11540/TR105.pdf? sequence $=2$ (accessed 3 March 2013).

Subramanian, R.S. (2007) Heat Transfer to or from a Fluid Flowing through a Tube [online] http://web2.clarkson.edu/projects/subramanian/ch302/notes/Convective $\% 20 H e a t \% 20$ Transfer \%201.pdf (accessed 3 March 2013).

Suresh, K.P., Mahanta, P. and Dewan, A. (2003) 'Study of laminar flow in a large diameter annulus with twisted tape inserts', Proceedings of Second International Conference on Heat Transfer, Fluid Mechanics, and Thermodynamics, Victoria Falls, Zambia, Paper Number KP3.

Vera-García, F., García-Cascales, J.R., Gonzálvez-Maciá, J., Cabello, R., Llopis, R., Sanchez, D. and Torrella, E. (2010) 'A simplified model for shell-and-tubes heat exchangers: practical application', Applied Thermal Engineering, Vol. 30, No. 10, pp.1231-1241.

Wang, S., Wen, J. and Li, Y. (2009) 'An experimental investigation of heat transfer enhancement for a shell-and-tube heat exchanger', Applied Thermal Engineering, Vol. 29, Nos. 11-12, pp.2433-2438.

Yadav, A. (2009) 'Effect of half-length twisted tape tabulator on heat transfer and pressure drop characteristics inside a double pipe U-bend heat exchanger', Jordan Journal of Mechanical and Industrial Engineering, Vol. 3, No. 1, pp.17-22.

Yildiz, C., Bicer, Y. and Pehlivan, D. (1996) 'Influence of fluid rotation on the heat transfer and pressure drop in double pipe heat exchangers', Applied Energy, Vol. 54, No. 1, pp.49-56.

Zohir, A.E., Aziz, A.A. and Habib, M.A. (2011) 'Heat transfer characteristics in a sudden expansion pipe equipped with swirl generators', International Journal of Heat and Fluid Flow, Vol. 32, No. 1, pp.352-362. 


\section{Nomenclature}

\begin{tabular}{|c|c|}
\hline$A$ & Area \\
\hline$C_{p}$ & Specific heat at constant pressure \\
\hline$d$ & Diameter of the tube \\
\hline$D$ & Diameter of the shell \\
\hline$D_{h}$ & Hydraulic diameter \\
\hline$h$ & Convective heat transfer coefficient \\
\hline$k$ & Thermal conductivity \\
\hline$L$ & Length of the required pipe \\
\hline$m$ & Mass flow rate \\
\hline$P$ & Pitch of the twisted-tape \\
\hline$q$ & Heat transfer rate \\
\hline$S$ & Regular space of the twisted-tape \\
\hline$T$ & Temperature of the fluids \\
\hline$T_{l m}$ & Log mean temperature difference \\
\hline$U$ & Overall heat transfer coefficient \\
\hline$V$ & Mean velocity \\
\hline$x$ & Distance \\
\hline Y & Twisted-Ratio \\
\hline$\mu$ & Viscosity of the fluids \\
\hline$\rho$ & Mass density of the fluids \\
\hline$G r$ & Grashof number \\
\hline$N u$ & Nusselt number \\
\hline $\operatorname{Pr}$ & Prandlt number \\
\hline $\operatorname{Re}$ & Reynolds number \\
\hline \multicolumn{2}{|c|}{ Subscripts } \\
\hline$c$ & Cold fluid \\
\hline$h$ & Hot fluid \\
\hline$i$ & Initial conditions \\
\hline$o$ & Outlet fluid conditions \\
\hline$S$ & Shell \\
\hline$T$ & Tube \\
\hline
\end{tabular}

